\title{
Geleneksel Olmayan Para Politikası Araçlarının Finansal İstikrar Üzerindeki Etkisi: Türkiye Uygulaması
}

\begin{abstract}
Sencan Felek ${ }^{\mathrm{a}}$, Resat Ceylan ${ }^{\mathrm{b}}$
Öz: 2007 yılında Amerika Birleşik Devletleri'nde başlayan ve 2008 yılında Türkiye'de de etkisini hissettiren küresel kriz, finansal istikrarın bir makroekonomik amaç olarak ele alınması gerçeğini ortaya çıkarmıştır. Dolayısıyla merkez bankaları makro ihtiyati politikalar çerçevesinde yeni para politikası araçları geliştirmişlerdir. Bu gelişmeler çerçevesinde bu çalışmanın temel amacı, 2008 küresel finansal kriz sonrası süreçte, 2011M1-2019M6 dönemleri arasında aylık veriler kullanılarak Türkiye Cumhuriyet Merkez Bankası (TCMB) tarafından uygulamaya konan geleneksel olmayan para politikası araçlarının finansal istikrar üzerindeki etkilerini araştırmaktır. Çalışmada, geleneksel olmayan para politikası araçlarından faiz koridoru, istisnai gün uygulaması ve kredi genişlemesinin, temel bileşenler analizi yardımıyla hesaplanan finansal istikrar endeksini etkileme kanalları SVAR yöntemi ile ortaya konmaktadır. Analizde; finansal istikrar endeksi, bir haftalık repo faiz oranı, nominal döviz kuru ve yurtiçi kredi hacmi değiş̧enleri kullanılmıştır. Elde edilen bulgulara göre, $T C M B^{\prime}$ nin kullandığı geleneksel olmayan para politikası araçlarından faiz koridoru ve istisnai gün uygulaması, finansal istikrarın sağlanmasında etkilidir. Parasal aktarım mekanizması döviz kuru kanalı ile çalışmaktadır.
\end{abstract}

\section{The Impact of Unconventional Monetary Policy Instruments on Financial Stability: The Case of Turkey}

Abstract: The global crisis, which started in the United States of America in 2007 and felt its impact in Turkey in 2008, revealed the fact that financial stability should be considered as a macroeconomic goal. Therefore, central banks have developed new monetary policy instruments within the framework of macroprudential policies. In the context of these developments, the main purpose of this study, in the aftermath of the 2008 global financial crisis, by using the 2011M1$2019 \mathrm{M} 6$ periods of monthly data, is to investigate the effects of unconventional monetary policy instruments implemented by the Central Bank of the Republic of Turkey (CBRT) on financial stability. In the study, the effects of interest rate corridor, exception day application, and credit expansion, which are unconventional monetary policy instruments, on the financial stability index calculated with the help of principal components analysis are revealed by the SVAR method. Financial stability index, one-week repo interest rate, nominal exchange rate, and domestic loan volume variables are used in the analysis. According to the findings, the interest rate corridor and exception day application, which are among the unconventional monetary policy tools used by the CBRT, are effective in ensuring financial stability. The monetary transmission mechanism works with the exchange rate channel.
Anahtar Sözcükler: Para Politikası, Faiz Koridoru, İstisnai Gün Uygulaması, Temel Bileşenler Analizi (PCA), Yapısal VAR

JEL: C10, C51, E52, E43, E58

$\begin{array}{ll}\text { Geliş } & : \text { 15 Nisan } 2021 \\ \text { Düzeltme } & : \text { 10 Haziran } 2021 \\ \text { Kabul } & : \text { 02 Temmuz 2021 } \\ \text { Tür } & : \text { Araştırma }\end{array}$

Keywords: Monetary Policy, Interest Rate Corridor, Exception Day Application, Principal Component Analysis (PCA), Structural VAR

JEL: C10, C51, E52, E43, E58
Received : 15 April 2021

Revised : 10 June 2021

Accepted : 02 July 2021

Type $\quad$ : Research

a PhD. Student, Pamukkale University, Social Sciences Institute, Denizli, sencanfelek@gmail.com (ORCID ID: 0000-0002-46726259)

b Prof., PhD., Pamukkale University, Faculty of Economics and Administrative Sciences, Department of Economics, Denizli, rceylan@pau.edu.tr (ORCID ID: 0000-0003-3727-6644) 


\section{Giriş}

2007 yılının ortalarında Amerika Birleşik Devletleri'nde (ABD) türev piyasalarda başlayıp sonrasında tüm dünya ülkelerini etkileyen küresel finansal kriz para politikası literatürüne bazı yenilikler getirmiştir. Yaşanan kriz daha önceki krizlerden farklı olarak, gelişmiş ülkelerde ortaya çıkmış ve domino etkisi yaratarak bütün ülkeleri etkisi altına almıştır. Dahası, düşük enflasyon oranlarına sahip ülkelerde bile finansal sistemin işlememesi sorununu beraberinde getirmiştir. Böylece, kriz öncesi dönemde fiyat istikrarı hedefine odaklanan para politikası otoritesi, finansal istikrarı da gözetmek durumunda kalmıştır. Türkiye Cumhuriyet Merkez Bankası (TCMB), bu gelişmelere paralel olarak Türkiye'de de derinden hissedilen küresel krizin etkilerini gidermek amacıyla para politikası anlayışını, finansal istikrarı kapsayacak şekilde yeniden dizayn etmek durumunda kalmıştır.

Literatürde, fiyat istikrarı ile finansal istikrar arasındaki ilişkiyi ele alan iki temel görüş bulunmaktadır. Birinci görüşe göre, fiyat istikrarının sağlanması, finansal istikrarı da garanti etmektedir. íkinci görüşe göre, fiyat istikrarının sağlanması tek başına finansal istikrarın tesis edilmesini garanti edemez. Bunun en çarpıcı örneği, 2000'li yılların başında bazı ekonomilerde enflasyon oranları düşük ve istikrarlı seyrettiği halde, finansal krizlerin meydana gelmesi ve enflasyonun yüksek seyrettiği dönemlerindeki gibi ciddi üretim kayıplarıyla karşılaşılmasıdır. Birinci görüşü savunan Papademos (2006), ekonomide fiyat istikrarının sağlanması durumunda faiz oranlarındaki risk primlerinin düşeceğini ve finansal piyasalardaki fiyat hareketliliğinin daha öngörülebilir duruma geleceğini ifade etmektedir. Bu çerçevede, fiyat istikrarının sağlanması ile birlikte finansal varlıklardaki aşırı risk eğilimi azalmakta ve finansal istikrar olumlu yönde etkilenmektedir. İkinci görüşü savunan Cuaresma ve Gnan (2008), Büyük Resesyon dönemine kadar merkez bankalarının tek amacının fiyat istikrarı olduğunu, ancak fiyat istikrarının sağlanmasına karşın ekonomide finansal istikrarın sağlanamadığını ve dolayısıyla sık sık finansal krizlerin ortaya çıktığını belirtmektedirler. Bu çerçevede Cuaresma ve Gnan (2008), fiyat istikrarının tek başına yeterli olmadı̆̆ını ve Büyük Resesyon sonrasında fiyat istikrarının yanında, finansal istikrar kavramının da önemli hale geldiğini belirtmektedirler. Gelişmiş ülke merkez bankaları, 2008 yılında yaşanan küresel finansal kriz karşısında toplam talebi canlandırmak için genişletici para politikaları uygulamaya başlamışlardır. Bu uygulama sonrasında piyasada likidite bolluğu oluşmuş ve piyasadaki bu likidite yapısal sorunları çözememiş, kamu borçları yüksek ve gelişmiş ülkelere kıyasla daha yüksek faiz oranına sahip gelişmekte olan ülkelere yönelmiştir. Başlangıçta krediye erişilebilirliğin artmasıyla iç talepte yaşanan canlanma, bu ülkelerin finansal krizden daha az etkilenmelerini sağlamıştır. Aynı zamanda ithal fiyatların düşük olması vesilesiyle de enflasyonla mücadelede de başarılı olmuşlardır (Çevik, 2016: 711-712). Yaşanan küresel finansal krizden gelişmekte olan ülkeler daha az etkilense bile sermaye akımının fazlalığı gelişmekte olan ekonomilere yeni problemleri ve bunların çözümü için yeni tedbirlerin alınması zorunluluğunu getirmiştir. Gelişmiş ülkelerde dış talebin zayıf olması ve ulusal para birimlerinin aşırı değerlenmesi cari hesap dengesizliklerinin hızla yükselmesine neden olmuştur. Bunun yanı sıra kontrolsüz kredi büyümesi de varlık fiyatlarında balonlara neden olmaya başlamıştır. Diğer yandan, gelişmekte olan ülkelere yönelmiş olan aşırı sermaye akımını ve bu durumun döviz kuru aracılı̆ıyla cari işlemler dengesi üzerinde oluşturacağı olumsuz etkileri önlemek amacıyla bazı ülkeler sermaye akımı önlemlerine başvurmuştur. Sermaye hareketlerinde liberalizasyondan yana olan Uluslararası Para Fonu (IMF), finansal krizin ardından, ülkelerin yeterli finansal ve kurumsal gelişme seviyesine ulaşıncaya kadar sermaye kontrolü uygulamalarının faydalı olabileceği görüşünü desteklemiştir. Ancak bu görüşe ek olarak IMF, alınan bu önlemlerin makroekonomik tedbirlerin yerini almaması gerektiğini de belirtmektedir (Akçelik vd., 2013: 5).

Bu gelişmelere bağlı olarak küresel finansal kriz, finansal istikrarın bir makroekonomik amaç olarak ele alınması gerçeğini ortaya çıkarmış ve TCMB'nin yeni para politikası araçları geliştirmesine neden olmuştur. Küresel finansal krizin neden olduğu etkiler karşısında, TCMB makro intiyati politikalar çerçevesinde yeni para politikası araçları kullanmaya başlamıştır. Bu araçlar; faiz koridoru, kredi genişlemesi, zorunlu karşılıklar, istisnai gün uygulaması ve rezerv opsiyon mekanizmasından oluşmaktadır. TCMB geleneksel olmayan yeni para politikası araçlarını uygulama aşamasında, aktarım kanalı olarak döviz kuru kanalını ve kredi kanalını kullanmıştır. 
TCMB'nin küresel finansal krizin olumsuz etkilerine karşı uygulamaya koyduğu yeni para politikası araçlarından faiz koridoru, kredi genişlemesi ve istisnai gün uygulamalarının finansal istikrarın sağlanmasındaki rollerinin belirlenmesi ve uygulanan yeni para politikası araçlarının hangi aktarım kanalı yolu ile çalıştığının ortaya konması bu çalışmanın temel sorusudur.

Kısa vadeli sermaye hareketlerinin ekonomide neden olduğu makroekonomik finansal riskleri en aza indirgemek amacıyla TCMB, 2010 yılının sonlarına doğru "faiz koridoru stratejisi" uygulamaya başlamıştır. Faiz koridoru uygulaması, TCMB'nin gecelik borç alma ve borç verme faiz oranları arasında kalan bant olarak ifade edilmektedir. Borç verme faiz oranı, geçici likidite sıkışıklığı yaşayan bir bankanın, merkez bankasından kısa vadeli borçlanarak ödemeye razı olduğu faiz oranını, borç alma faiz oranı ise bankanın faiz getirisi sağlayabilmek için elinde bulunan fazla likiditeyi merkez bankasına mevduat olarak yatırması sonucunda almayı kabul ettiği faiz oranını ifade etmektedir. Söz konusu yapının bir gereği olarak piyasa faizleri faiz koridorunun içinde oluşmaktadır. Diğer yandan mevcut uygulamada merkez bankası piyasayı fonlamayı 1 haftalık repo faizi aracılığıyla yaptığı için, "politika faizi" olarak 1 haftalık repo faiz oranı kullanılmaktadır (Vural, 2013: 63).

Faiz koridoru uygulaması, piyasa faiz oranının, politika faiz oranlarından belirgin bir biçimde sapmasını engelleyerek, sermaye akımlarına ve döviz kuru oynaklığına yol açacak finansal dalgalanmaların olumsuz etkilerini ortadan kaldırmayı sağlayan bir araç olarak düşünülmüştür. TCMB, gerekli gördüğünde faiz koridorunun genişliğini asimetrik bir şekilde ayarlayabilmektedir. Dolayısıyla da TCMB'nin faiz koridorunu aktif bir araç olarak kullandığı gözlenmektedir (TCMB, 2012: 4-5). Bu uygulama ile TCMB, kısa vadeli sermaye hareketlerindeki oynaklığa hızlı ve esnek bir tepki verebilmekte, böylece döviz kuru ve kredi büyümesi üzerinde ortaya çıkması muhtemel olan olumsuz etkilere karşı durabilmektedir.

TCMB geleneksel para politikası uygulamalarında devlete ya da özel sektöre doğrudan kredi vermezken, aynı zamanda devlet tahvili, şirket borç veya borç enstrümanlarının alımını da gerçekleştirmez. Kredi genişlemesi politikası, belirli bir piyasa segmentinde şirket bonoları, ticari kağıt ve varlığa dayalı menkul kıymetler aracılığıyla merkez bankasının doğrudan likidite sağlaması yöntemidir. Bu yöntemin; bankacılık sektörünün koşullarını iyileştirmek, banka kredilerini teşvik etmek ve banka fonlama maliyetlerini azaltmak amacıyla uygulanması düşünülmüştür. Dolayısıyla kredi genişleme politikası kısa vadeli riskli varlıkları kısa vadeli güvenilir varlıklarla yapılandırmaktadır (Bernanke vd., 2004; Farmer, 2012).

Kredi genişlemesinin uygulanması, merkez bankasının kısa vadeli hazine bonosu satması ve bu vadede ticari menkul kıymet almasıyla gerçekleşmektedir. Bu durumda merkez bankasının bilanço büyüklüğü ile vadesi aynı kalmakta ve sadece bilançonun kompozisyonu değişmektedir. Bunun yanı sıra riskli varlıkları piyasadan çekmek ve kredilerin maliyetlerini azaltmak için merkez bankası bilançosuna piyasadaki riskli menkul kıymetler yazılmakta, risksiz menkul kıymetler ise piyasaya sürülmektedir (Borio ve Disyatat, 2009).

Kredi genişleme politikası aracının diğer bir yönü de teminatların kalitesidir. Merkez bankasının gerçekleştirmiş olduğu yeniden finansman işlemlerinde, teminat kabul edilen varlıkların çeşitlendirilmesi ve bu sektörlere finansman koşullarının kolaylaştırılması gerekmektedir. Piyasanın sıkıntı içerisinde olduğu dönemlerde kalitesi düşük olan varlıkların büyük miktarlarda kullanılması bankalar için doğal bir eğilim olarak gözlenmektedir. Merkez bankasının aktarmış olduğu toplam teminat, finansal piyasaların streste olduğu durumlara bağlı olarak içsel değişkenliğe neden olmaktadır (Tunalı ve Yalçınkaya, 2016: 78).

Vural (2013); istisnai gün ifadesini, TCMB'nin haftalık repo ihalesi açmadığı günler olarak tanımlamaktadır. TCMB, bu istisnai gün olarak belirtilen günlerde doğrudan döviz satışları gerçekleştirmektedir ve aynı zamanda gün içi döviz satım ihaleleri de düzenleyerek beklentilerin yönetilmesini hedefleyebilmektedir. TCMB istisnai gün uygulamasında, parayı piyasaya ihale yöntemiyle sürmekte ve bankalar da piyasanın sıkışıklık durumuna göre taleplerini artırmaktadır. Böylece ihaledeki oran, faiz koridorunun üst sınırına yaklaşmaktadır. Bu uygulama ile TCMB dolaylı olarak faizlerin artmasını sağlamakta, kur üzerinde baskı oluşturmakta ve TL'nin değer kazanmasını hedeflemektedir.

TCMB, "istisnai gün" olarak ilan ettiği günlerde, spekülatif baskıların döviz kurunun hareketlerini etkileyebileceği sinyalini vermektedir. Bankanın istisnai gün içinde yarattığı göreli likidite sıkışıklığı, kurun 
değeri üzerinde belirgin bir gün içi baskı oluşturmayabilir, ancak piyasaların TCMB'nin duruşunu koruyacağını varsayması durumunda spekülatif baskılar sınırlanmaktadır. TCMB'nin bu uygulaması kurun seviyesine ilişkin bir taahhüde dayanmamaktadır. Bu uygulama ile kur oynaklığının sınırlanması yoluyla finansal istikrarsızlık ve enflasyon beklentilerinin bozulmasının önüne geçilmesi amaçlanmaktadır. Buradan hareketle, politika araçlarının değişkenlik gösterebildiği ve bankanın döviz kuruna yönelik bakış açısının kriz öncesi dönemle tutarlılık arz ettiği söylenebilmektedir.

Bu çalışmada, makro ihtiyati politikalar çerçevesinde Türkiye'de uygulanan geleneksel olmayan para politikaları araçlarından faiz koridoru, istisnai gün uygulaması ve kredi genişlemesinin finansal istikrar üzerindeki etkisi incelenmektedir. TCMB'nin uygulamakta olduğu geleneksel olmayan para politikası araçlarının finansal istikrarı sağlayıp sağlamadığı konusu tespit edilirken, TCMB'nin bu politikaları hangi kanallar aracılığıyla yaptığı da önem arz etmektedir. Dolayısıyla çalışmada para politikası araçlarının yanı sıra parasal aktarım mekanizmalarına da değinilmektedir. Çalışmanın geri kalan kısmı şu şekilde organize edilmektedir: i̇kinci bölümde, para politikalarının ve parasal aktarım mekanizması kanallarının finansal istikrar üzerindeki etkisi teorik açıdan ele alınmaktadır. Üçüncü bölümde merkez bankalarının uygulamış oldukları para politikası araçlarının finansal istikrar üzerindeki etkilerini inceleyen literatür çalışmasına yer verilmektedir. Son bölümde ise Türkiye'de 2010 yılından sonra uygulanmaya başlayan yeni para politikası araçlarından faiz koridoru, istisnai gün uygulaması ve kredi genişlemesi politikalarının, temel bileşenler analizi yardımı ile oluşturulan finansal istikrar endeksi üzerindeki etkisi yapısal vektör hata düzeltme modeli (structural vector autoregression; SVAR) yöntemi ile incelenmekte ve çalışma bulguları tartışımaktadır.

\section{Teorik Altyapı}

Parasal aktarım kanallarına etki eden en önemli faktör merkez bankaları tarafından seçilen para politikası araçlarıdır. Merkez bankalarının aktarım mekanizmasının nasıl çalıştığının kavranması, kullanılan para politikası araçlarının üretim seviyesi ve enflasyona etki düzeyi ile ortaya çıkan bu etkileşimin sürecinin bilinmesi açısından önemlidir.

Çalışmanın bu kısmında TCMB'nin kullanmış olduğu parasal aktarım kanalları hakkında kısaca bilgi verilecektir. Çünkü TCMB'nin yeni para politikası stratejisinde parasal aktarım kanallarından faiz kanalı, kredi kanalı ve döviz kuru kanalını kullandığı görülmektedir.

Faiz Oranı Kanalı: Geleneksel aktarım kanalı olan faiz oranı kanalı Keynesyen aktarım kanalı olarak bilinmektedir. Faiz oranı kanalı, borç paranın marjinal maliyetini değiştirmektedir ve bundan dolayı ekonomik birimlerin nakit akışı ile tüketim tercihlerini etkilemektedir. Aynı zamanda bu durum üreticilerin tasarruf, yatırım ve toplam talebini de etkilemektedir. Reel faiz oranlarında meydana gelen bir düşüş sermeyenin maliyetini de düşürerek yatırım harcamalarını artırmaktadır ve bunun sonucunda toplam talep artmakta, çıktılar yükselmektedir (Cotarelli ve Courelis, 1994: 75). Harcamalar üzerinde en önemli etki uzun dönem reel faiz oranları tarafından belirlenmektedir. Yani ekonomik birimler kararlarını daha çok reel faiz oranlarına bağlı olarak vermektedirler. Parasal otorite nominal faiz oranlarında bir değişiklik yaptığında bu durum kısa dönemde nominal fiyatların yapışan olmasından dolayı kısa ve uzun dönem reel faiz oranlarını etkilemektedir. Genişleyici para politikası nominal faiz oranlarının ve akabinde reel faiz oranlarının da düşmesine neden olmaktadır (Mishkin, 1995: 5). Dolayısıyla reel faiz oranlarının düşmesi hem tüketim malları harcamalarını hem de yatırımları artıracaktır. Bu durum ise reel ekonomide üretim ve istihdam artışlarını da beraberinde getirecektir.

Döviz Kuru Kanalı: Merkez bankasının para politikası uygulamaları sonucunda döviz kurunda meydana getirdiği değişikliklerin dış talebi etkilemesiyle birlikte toplam harcamalar, milli gelir ve enflasyon üzerindeki etkileri ortaya çıkmaktadır. Döviz kuru kanalı, faiz oranı kanalını dolayısıyla geleneksel Keynesyen yaklaşımı temel alarak aktarım mekanizmasını açıklamaktadır. Ayrıca döviz kuru kanalı, faiz kanalı kadar ekonomik göstergeleri etkileyen önemli değişkenlerden birisidir (Belke ve Kaya, 2017: 187).

Döviz kuru kanalının teorik temelleri, uygulanan para politikası yerli ve yabancı yatırım kararlarını döviz kuru aracılı̆̆ıyla etkilediği için, Mundell-Fleming modelinin tam sermaye hareketliliği ve esnek döviz kuru sisteminin geçerli olduğu versiyonuna dayanmaktadır. Esnek döviz kuru sistemi ve sermaye 
hareketliliğinin sınırsız olması koşulu altında genişletici para politikası uygulamaları gelir artışına ve yerli paranın değer kaybetmesine neden olmaktadır. Döviz kurlarında meydana gelen artışların olumlu etkileri ise parasal genişlemenin gelir ve toplam talep üzerindeki olumlu etkilerini artırmaktadır (Snowdon ve Vane, 2005: 118).

Uluslararası sermaye hareketlerinin serbestleştiği ve faiz esnekliğinin yüksek olduğu bir ortamda uygulanan para politikası faiz oranları yolu ile döviz kurunu da etkilemektedir. Faiz oranlarındaki değişmeler uluslararası sermaye hareketlerinin hacmini ve bunun sonucunda yerli paranın değerini etkileyerek döviz kurunu değiştirmektedir. Tüm bunların sonucunda uluslararası ticarete konu olan malların fiyatlarında ve ticaret hacminde değişiklikler olmaktadır (Cengiz, 2009: 233).

Merkez bankası uyguladığı genişletici para politikası aracılığıyla para arzını artırıp faiz oranlarını düşüreceği için, sermaye hareketliliğinde değişiklik olacaktır. Yurt içi faiz oranları düştüğünde yabancı yatırımcılar, faiz oranı yüksek olan başka bir ülkeye yatırım yapmak isteyecek, dolayısıyla ülkeden sermaye çıkışı yaşanacaktır. Bunun sonucu olarak da döviz miktarı azalacak ve döviz kuru yükselecektir. Dolayısıyla yerli para değer kaybedecek ve yurtiçinde üretilen malların değerinin, yabancı mallardan daha ucuz hale gelmesi söz konusu olacaktır. Döviz kurunun artması net ihracatı doğrudan etkilediğinden, üretim ve hasıla düzeyi de yükselecektir.

Kredi Kanalı: Para politikası uygulamaları, önce banka rezervlerini sonra da mevduat-kredi mekanizması yoluyla bankaların mevduatlar üzerinden borç verme olanaklarını etkilemektedir. Dolayısıyla reel sektörün yeni yatırımlar için finansman sağlama olanakları ve hasıla düzeyi üzerinde de etki sahibidir. Buna ek olarak finansal piyasaların düzgün çalışmayışı, reel sektörde faaliyet gösteren firmaların kredi maliyetini yükseltmekte ve firmaların kredibilitesinin düşmesine neden olmaktadır. Merkez bankası daraltıcı para politikası uygulaması durumunda fon miktarında düşüş gerçekleşecek ve bu durum, yatırım harcamalarının ve toplam talebin azalmasına, işsizlik oranının da yükselmesine neden olacaktır (Arıkan vd., 2018: 9).

Kredi kanalında zorunlu karşılık oranlarının da önemli bir etkisi vardır. Merkez bankası zorunlu karşılık oranlarını arttırdığında bankaların kredi verebileceği mevduatları azalmaktadır. Buna bağlı olarak da kredi yaratma süreci azalmış olmaktadır.

\section{Literatür Taraması}

Bernanke ve Blinder (1992) ile Bagliano ve Favero (1998)'nun çalışmaları literatürde para politikasının etkinliği konusunda yapılan temel analizlerdir. Büyük Buhran'dan sonra para politikasının sadece fiyat istikrarını sağlanmaya odaklanması gerektiği yönündeki genel düşünce terkedilmiştir. Bu çerçevede, Bernanke (2010), para politikasının, istisnai durumlarda makroekonomik istikrarı gerçekleştirme hedefinin ötesine geçmesi gerektiğini ileri sürerken, Borio ve Drehmann (2009), para politikasının kullanımının finansal istikrarın sağlanabilmesi için önemli olduğunu belirtmektedirler.

Sinclair (2000)'e göre, finansal istikrarın sağlanabilmesi için, finans piyasalarının düzgün işlemesi ve para politikalarına etkilerinin olumlu olması gerekmektedir. Para politikalarının fiyat istikrarını sağlayamaması durumunda, enflasyonda dalgalanma meydana gelmesi ve beklenmedik bir artış gerçekleşmesi, gelirin borç verenlerden borç alanlara doğru yönelmesine neden olacaktır. Tersi durumda da enflasyonda beklenmedik bir düşüş gerçekleştiğinde gelirin borç alanlardan borç verenlere yönelmesine sebep olacaktır. Sonuçta iki durumda da kredi kalitesi olumsuz etkilenecek ve banka iflaslarıyla karşı karşıya kalınabilecektir. il|gili bankaların büyüklüğü ve çokluğuna göre de finansal istikrarsızlık oluşacaktır.

2008 yılında yaşanan küresel finansal krizden sonra, makro ihtiyati politikalar çerçevesinde, küresel krizin merkez bankaları üzerindeki etkilerini hafifletmek ve fiyat istikrarından ödün vermeksizin finansal istikrarı sağlamak için birçok ülkede geleneksel olmayan para politikası araçları uygulanmaya başlanmıştır. Finansal istikrarın sağlanmasına yönelik politikalar, makro ihtiyati politikalar olarak adlandırılmış ve makro intiyati politikaların etkinliği üzerine yapılan analizlerde literatür, krizin etkisiyle birlikte gelişim göstermiştir. 
Bu bağlamda, literatürde geleneksel olmayan para politikalarının ve makro ihtiyati politikaların etkinliğine ilişkin çalışmalar son zamanlarda yoğunlaşmıştır.

Para politikası analizlerinde literatürde, çoğunlukla çok değişkenli gecikmesi dağılmış VAR yaklaşımları kullanılmaktadır. Bunun nedeni ise VAR yaklaşımlarının, yaşanan iktisadi şokların makro iktisadi değişkenler üzerinde kısa ve uzun dönemli etkilerinin dinamik bir etkileşim süreci etrafında analiz edilmesine imkân sağlamasıdır (Bagliano ve Favero, 1998: 1070-1072). 2008 küresel finansal krizinden sonra merkez bankaları fiyat istikrarı ile birlikte finansal istikrara ulaşılması gerektiği üzerinde durmuşlardır. Bu konudaki literatür çoğunlukla VAR yaklaşımlarına dayalıdır.

Finansal istikrar endeksi ile ilgili çalışmalar genel olarak gelişmiş ülkeler üzerine yapıldığından Türkiye'de bu alanda yapılan çalışmalar oldukça sınırlı sayıdadır. Gelişmiş ülkelerde ise oluşturulan endeksler genellikle "Finansal Koşullar Endeksi" olarak hesaplanmıştır. Bu çalışmada literatür taraması öncelikle endeks oluşturmadan finansal istikrarın göstergesi olan değişkenler üzerine yapılan öncelikli birkaç çalışmaya değinilmiş, sonrasında finansal koşullar endeksi oluşturularak yapılan çalışmalara yer verilmiştir.

Bernanke ve Blinder (1992) ABD için 1959-1989 yılları arası dönemde aylık verileri kapsayan çalışmalarında para, kredi ve gelir arasındaki ilişkiyi SVAR yöntemiyle incelemişlerdir. Çalışmanın sonucunda para politikalarının krediler üzerinde etkili olduğunu ve daraltıcı para politikasında yaşanan bir şokun akabinde kısa vadeli menkul kıymetlerin kredilerden daha hızlı arttığını tespit etmişlerdir.

Lim vd. (2011), 2000-2010 yılları arasında 48 ülke için para politikaları ile finansal istikrar arasındaki ilişkiyi panel GMM analizi yöntemi ile test etmişlerdir. Analizde finansal istikrar göstergesi olarak kredi büyümesi ve kaldıraç büyümesi değişkenleri ile makro intiyati araç göstergeleri olarak politika faiz oranı ve GSYiH büyüme oranı değişkenleri kullanılmıştır. Çalışmanın sonucunda elde edilen bulgulara göre, makro intiyati araçlar kredi büyümesini ve kaldıraç büyümesini azaltmakta, dolayısıyla finansal istikrarın sağlanmasına katkıda bulunmaktadır.

Oktar ve Dalyancı (2011), Türkiye için 2003-2010 dönemleri arasında aylık veriler kullanarak cari işlemler dengesi ile para politikası arasındaki ilişkiyi VAR ve Granger nedensellik analizi ile incelemişlerdir. Finansal istikrar göstergesi olarak cari işlemler dengesini bağımlı değişken ve para politikası değişkeni olarak da TCMB politika faizini bağımsız değişken olarak ele almışlardır. Çalışmanın sonucunda, para politikası ile cari işlemler dengesi arasında kısa dönemde Granger nedenselliğin söz konusu olmadığı, ancak uzun dönemde değişkenler arasında ters yönlü eşbütünleşme ilişkisi bulunduğu tespit edilmiştir. Dolayısıyla yazarlar çalışmalarında, finansal istikrarın sürdürülebilirliği için uygulanan para politikasının, cari işlemler dengesini olumlu yönde etkilemesi gerektiğini belirtmişlerdir.

Glocker ve Towbin (2012), Brezilya için 1999:7-2010:12 yılları arasında aylık verileri kullanarak Bayesian VAR analizi yapmışlardır. Çalışmada finansal istikrar göstergesi olarak yurtiçi kredi hacmi değişkeni, para politikası araçlarından da zorunlu karşıık oranı ve politika faiz oranı değişkenleri kullanılmıştır. Çalışmanın sonucunda, zorunlu karşılık ve faiz oranlarındaki artışın yurtiçi kredi büyümesinde daralmaya neden olduğu ve dolayısıyla zorunlu karşııık oranlarının finansal istikrara katkı sağladığı bulgusuna ulaşılmıştır.

Tovar vd. (2012), rezerv gereksinimlerinin ve diğer makro ihtiyati politikaların özel sektör banka kredileri üzerindeki etkilerini incelemek amacıyla, 2003:1-2011:4 dönemi verilerini kullanarak beş Latin Amerika ülkesi üzerine panel VAR çalışması yapmışlardır. Çalışma sonucunda, rezerv gereksinimlerinin kredi büyümesinde kısa vadeli bir etkiye sahip olduğu tespiti yapılmış, ayrıca para politikası ve diğer makro ihtiyati araçların finansal istikrar açısından tamamlayıcı nitelikte olduğu sonucuna varılmıştır.

Dell’ Aricca vd. (2015), 1970-2010 yılları arasında 170 ülke için panel regresyon yöntemini kullanarak yaptıkları çalışmanın sonucunda, makro ihtiyati politika araçlarının finansal istikrarı sağlamada etkili olduğu ve kredi piyasasında oluşan balonları sınırlandırmada önemli olduğu bulgularına ulaşmışlardır.

Fendoğlu (2015), 15 ülke için 2004:1-2013:2 arası dönem verilerini ve panel GMM yöntemini kullandığı çalışmasında, para politikası araçları ile finansal istikrar göstergelerinden reel kredi büyümesi ve net sermaye girişleri arasındaki ilişkiyi test etmiştir. Çalışmanın sonucuna göre, para politikası uygulamaları 
reel kredi büyümesini ve sermaye girişlerini azaltmakta dolayısıyla finansal istikrarı pozitif yönde etkilemektedir.

Eroğlu ve Kara (2017), 2010:1-2016:6 dönemi arasında aylık verileri kullanarak Türkiye için para politikaları ile finansal istikrar arasındaki ilişkiyi VAR analizi ile test etmişlerdir. Çalışmada finansal istikrar göstergeleri olarak toplam kredi hacmi ve sermaye hareketleri dengesi, para politikası araçları olarak da TCMB borç alma - borç verme faiz oranı arasındaki farkı gösteren faiz koridoru, TL-YP zorunlu karşılık oranları, 1 aylık repo faiz oranı ve politika faiz oranı değişkenleri kullanıımıştır. Çalışmadan elde edilen bulgular, para politikası araçlarının finansal istikrar üzerindeki etkisinin zayıf olduğu yönündedir.

Kılcı (2019), 2010:1-2019:2 dönemlerini kapsayan çalışmasında, Türkiye'de Merkez Bankası'nın fiyat istikrarı ile birlikte finansal istikrarı da sağlayıp sağlamadığını test etmiştir. Yeni para politikası araçlarından faiz koridoru uygulamasının finansal istikrar üzerine etkilerinin incelendiği çalışmada; faiz koridoru değişkeni olarak TCMB ağırlıklı fonlama faiz oranı değişkeni, finansal istikrar değişkeni olarak da bankacılık sektörü kredi hacmi ve döviz kuru kullanılmıştır. Çalışmada değişkenler arasındaki ilişki Fourier eşbütünleşme ve Granger nedensellik testi ile test edilmiştir. Çalışmadan elde edilen bulgular, TCMB'nin ağırlıklı fonlama faiz oranının kredi hacmi ve döviz kurları üzerinde etkili olduğu, dolayısıyla bankacılık sektörü ve reel ekonomi açısından da önemli rol oynadığı yönündedir.

Goodhart ve Hofmann (2001) G7 ülkelerini kapsayan çalışmalarında finansal koşullar endeksi oluşturmak için reel efektif döviz kuru, kısa dönem reel faiz oranı, reel hisse senedi fiyatları ve reel konut fiyatları değişkenlerini kullanmışlardır. Yazarlar bu endeksi oluştururken indirgenmiş form toplam talep modelinden yararlanmışlar ve sonrasında VAR analizi yardımıyla etki-tepki fonksiyonlarını kullanmışlardır. Yapılan çalışmanın sonucunda varlık fiyatlarının üretim açığını olumlu yönde etkilediği gözlenmiştir. VAR etkitepki sonuçlarına göre ise konut fiyatları ve faiz oranlarına bir şok uygulandığında, bu durumun enflasyonu ve üretim açığını anlamlı şekilde etkilediği tespit edilmiştir. Ancak buna ek olarak döviz kuruna bir şok verilmesi durumunda bu şokların analizi yapılan ülkelerin sadece yarısında anlamlı etkilere sahip olduğu tespit edilmiştir.

Osorio vd. (2011) 2001-2011 yılları arasında, 13 ülke için, VAR etki-tepki fonksiyonları ve temel bileşenler yöntemlerini kullanarak, Finansal Koşullar Endekslerinin GSYiH'yı öngörü güçlerini değerlendirilmiştir. Elde edilen endeks sonuçlarına göre; küresel kriz öncesinde finansal koşullarda yaşanan daralmanın, hisse senedi piyasalarındaki kayıplar ve kredi imkanlarının daralması nedeniyle ortaya çıktığı tespit edilmiştir. 2010 yılının ilk aylarında uygulanan para politikaları ve varlık fiyatlarındaki toparlanma sayesinde finansal koşulların kriz öncesi seviyelere ulaştığı tespit edilmiştir.

Angelopoulou vd. (2014) parasal birlik içerisindeki Portekiz, Almanya, İspanya, Yunanistan gibi ülkeler ile Euro bölgesi için Finansal Koşullar Endeksini, 2003-2011 dönemi aylık verileri kullanarak hesaplamışlardır. Sadece para politikası değişkenlerinden yararlanılarak hesaplanan endeksin, özellikle küresel finansal kriz döneminde finansal koşullardaki daralmayı tespit etmede başarılı olmadığı gözlenmiştir. Yani, para politikası değişkenlerinin, finansal koşullardaki değişimlerin sadece küçük bir kısmını açıklayabildiği görülmüştür.

Gerek Türkiye gerekse diğer ülkelere ilişkin yapılan çalışmalarda, para politikası araçlarının finansal istikrar üzerindeki etkilerinin genellikle finansal istikrarı gösteren bir veya birkaç değişken ele alınarak incelendiği görülmektedir. Ancak finansal istikrar çok sayıda değişken tarafından belirlenebilmekte ve bu değişkenlerin bazılarının göz ardı edilmesi durumu finansal istikrarın yönünde sapmalara neden olabilmektedir. Bu nedenle finansal istikrarda görülen sapmaların belirlenebilmesi için değişkenlerin doğru seçilmesi önemlidir. Bu bilgiler çerçevesinde çalışmada, 14 adet finansal istikrar değişkeni kullanılarak tek bir finansal istikrar endeksi oluşturulmuştur. Böylece çalışmada geleneksel olmayan para politikası araçlarının bir veya birkaç finansal istikrar değişkeni üzerindeki etkisinden ziyade çok sayıda finansal istikrar değişkeni tarafından elde edilen tek bir finansal istikrar endeksi üzerindeki etkisinin tespit edilmesi amaçlanmaktır. Dolayısıyla bu çalışmayı literatürde yapılan diğer çalışmalardan ayıran en önemli fark, 14 adet finansal istikrarı gösteren değişkenlerden elde edilen tek bir finansal istikrar endeksinin analize dahil edilmesidir. Bu çerçevede çalışmada Türkiye için finansal istikrarın az sayıda değişkenle temsil edilmesinin yeterli ve doğru bilgiyi vermeyeceği öngörüsüyle 2011M1-2019M6 dönemleri arasında 14 adet finansal istikrarı temsil eden 
değişken aracılığıyla temel bileşenler analizi (Principle Component Analysis; PCA) kullanılarak finansal istikrar endeksi oluşturulmuştur.

\section{Ekonometrik Yöntem}

2008 yılında Amerika'da başlayan ve etkisini 2009 yılında Türkiye'de de gösteren küresel finansal krizden sonra TCMB uyguladığı para politikası araçları ile hem fiyat istikrarı hem de finansal istikrarı sağlamayı amaçlamıştır. Bu çalışmada, TCMB'nin uygulamaya başladığı yeni para politikası araçlarının belirlenen hedeflere ulaşmadaki etkinliği analiz edilmektedir. Analiz aracı olarak yapısal vektör hata düzeltme modeli (SVAR) kullanılmıştır. Çalışmada öncelikle 14 finansal istikrar değişkeni ile finansal istikrar endeksi oluşturma yöntemlerinden biri olan temel bileşenler analizi (PCA) hakkında bilgi verilmiştir. Akabinde de 2011M12019 M6 dönemi aylık verileri kullanılarak TCMB tarafından uygulanan yeni para politikası araçlarının finansal istikrara etkisi yapısal VAR yöntemi ile analiz edilmiştir.

\subsection{Temel Bileşenler Analizi (PCA) Yöntemi ile Endeks Oluşturma}

Çok sayıda değişken ile açıklanabilen finansal istikrar düzeyinin tespit edilmesi ve ölçülmesi konusunun güç olduğu, bu konuda bir fikir birliği olmadığı ve net bir hesaplamanın yapılmasının mümkün olmamasından dolayı araştırmacılar farklı yöntemler kullanarak ölçümler gerçekleştirmektedirler. Finansal istikrar belirtildiği gibi çok sayıda değişken tarafından açıklanabilmekte ve değişkenlerden bazılarının ihmal edilmesi durumunda finansal istikrarda sapmalar meydana gelebilmektedir. Dolayısıyla bu çalışmada Türkiye için finansal istikrarın birkaç değişkenle açıklanmasının sağlıklı sonuçlar vermeyeceği düşüncesiyle 2011M12019M6 dönemi için 14 adet finansal değişkenle finansal istikrar endeksi oluşturulmuştur. Söz konusu 14 adet finansal istikrar değişkeni Tablo'1 de gösterilmektedir.

Tablo 1. Değişkenlerin Tanımı

\begin{tabular}{|l|l|l|l|}
\hline m3 & Logaritması alınmış para arzı & gbd & Genel bütçe dengesi/GSYiH \\
tkh1 & Toplam kredi hacmi/GSYiH & tbsgdp & Toplam borç stoku/GSYiH \\
io & İşsizlik oranı & ibfövg & i̇ç borç faiz ödemeleri/Vergi gelirleri \\
$\mathbf{d i b s}$ & Devlet iş borçlanma senetleri faiz oranları & $\mathbf{s y r}$ & Sermaye yeterlilik rasyosu \% \\
cd & Cari denge/GSYiH & $\mathbf{t k t m}$ & Toplam krediler/Toplam mevduat \\
kvdbmbr & $\begin{array}{l}\text { Kısa vadeli dış borç/TCMB brüt döviz } \\
\text { rezervleri }\end{array}$ & lyo & Logaritması alınmış likidite yeterlilik oranı \\
dth & Dış ticaret haddi & btatk & Brüt takipteki alacaklar/toplam nakdi krediler \% \\
\hline
\end{tabular}

Tablo 1'de finansal istikrarı gösteren değişkenlerden geniş tanımlı Para Arzı (M3) Kara vd. (2015), Toplam Kredi Hacmi/GSYiH ve Dış Ticaret Haddi değişkenleri, Eroğlu ve Kara (2017), DiBS, Genel Bütçe Dengesi/GSYiH, Toplam Borç Stoku/GSYiH, İç Borç Faiz Ödemeleri/Vergi Gelirleri, İ̧sizlik Oranı ve Sermaye Yeterlilik Rasyosu değişkenleri Aktaş (2011)'ın çalışmalarından derlenmiştir. Bunlara ek olarak Likidite Yeterlik Oranı, Cari Denge/GSYiH ve Kısa vadeli Dış Borç/Merkez Bankası Brüt Döviz Rezervleri değişkenleri, Sanar (2014)'ın çalışmasından ve Brüt Takipteki Alacaklar/Toplam Nakdi Krediler ile Toplam Krediler/Toplam Mevduat değişkenleri Tiryaki (2012)'nin çalışmasından derlenmiştir.

Temel bileşenler analizi (PCA), değişken azaltma analizi olarak tanımlanmaktadır. Çok sayıda değişkenle anlatılmak isteneni az sayıda bileşenle anlatılmasını sağlayan ve bu alanda sıklıkla kullanılan bir yöntemdir (Dunteman, 1989: 8).

PCA için değişkenlere karar verilirken değişkenlerin birbirleriyle arasındaki bağlantıya dikkat edilmelidir. Değişkenlerin birbirleriyle ilişkisinin çok düşük veya çok yüksek olması elde edilen faktör sonuçlarını etkilemektedir. Eğer aralarındaki ilişki yüksek olursa bu durum çoklu bağıntı (multicollinearity) sorununa neden olabilmektedir. Bu sorunun olmaması için veri uygunluğunun test edilmesi ve birbirleriyle çok düşük veya çok yüksek bağlantılı değişkenlerin analize dahil edilmemesi gerekmektedir (OECD, 2005: 4041). Bu veri uygunluğu testlerinden biri olan KMO testi, değişkenler arasındaki ilişkilerin önem derecesini ve 
kullanılan verilerin bu analize uygunluğunu ölçmektedir. Elde edilen $\mathrm{KMO}$ değeri 0,60 'dan büyük ise bu durum kullanılan değişkenlerin analiz için yeterli derecede uygun olduğunu ifade etmektedir. Temel bileşenler analizinde SPSS 21 paket programı kullanılmıştır ve KMO değeri \%73,9 olarak bulunmuştur. Tablo 2'de belirtilen bu değerin \%73,9 olması temel bileşenler analizinde kullanılan veri setinin yeterince uygun olduğunu söylemek mümkündür. Aynı zamanda bu sonuç, değişkenlerin korelasyonunun diğer değişkenler tarafından iyi derecede açıklandığını da göstermektedir.

Tablo 2. KMO ve Bartlett's Testi Sonuçları

\begin{tabular}{|l|r|}
\hline Kaiser-Meyer-Olkin Measure of Sampling Adequacy & 0,739 \\
\hline Bartlett's Approx. Chi-Square & 1978,002 \\
Test of Df & 91 \\
Sphericity Sig. & 0 \\
\hline
\end{tabular}

Tablo 3'te finansal istikrar değişkenlerinin temel bileşenler analizindeki açıklama oranları ve varyansları gösterilmiştir. Temel bileşenler analizinde değişkenlerin varyansı 1'den büyük olan bileşenler, faktör sayısının belirlenmesi için yeterlidir. Dolayısıyla varyansı 1'den küçük olanlar değerlendirmeye alınmamıştır.

Tablo 3. Temel Bileşenlerin Varyansları ve Açıklama Oranları

\begin{tabular}{|l|r|r|r|r|r|r|}
\hline \multirow{3}{*}{ Bileşen } & \multicolumn{3}{|c|}{ Özdeğer } & \multicolumn{3}{|c|}{ Yüklerin Kareleri Toplamı } \\
\cline { 2 - 7 } & Toplam & $\begin{array}{c}\text { Varyans } \\
\%\end{array}$ & Birikimli \% & Toplam & $\begin{array}{r}\text { Varyans } \\
\%\end{array}$ & $\begin{array}{c}\text { Birikimli } \\
\%\end{array}$ \\
\hline 1 & 6,567 & 46,908 & 46,908 & 6,567 & 46,908 & 46,908 \\
2 & 2,842 & 20,3 & 67,208 & 2,842 & 20,3 & 67,208 \\
3 & 1,091 & 7,79 & 74,998 & 1,091 & 7,79 & 74,998 \\
4 & 0,969 & 6,921 & 81,919 & & & \\
5 & 0,871 & 6,221 & 88,141 & & & \\
6 & 0,687 & 4,908 & 93,049 & & & \\
7 & 0,368 & 2,626 & 95,674 & & & \\
8 & 0,208 & 1,486 & 97,16 & & & \\
9 & 0,161 & 1,148 & 98,308 & & & \\
10 & 0,107 & 0,761 & 99,07 & & & \\
11 & 0,075 & 0,537 & 99,607 & & & \\
12 & 0,043 & 0,304 & 99,911 & & & \\
13 & 0,011 & 0,075 & 99,986 & & & \\
14 & 0,002 & 0,014 & 100 & & & \\
\hline
\end{tabular}

Tablo 3'te görüldüğü gibi 14 bileşenden üç tanesinin varyansı birden büyüktür. Toplam varyansın \%46,908'ini birinci temel bileşen, \%20,300'ünü ikinci temel bileşen, \%7,709'unu üçüncü temel bileşen açıklarken üç bileşen birlikte toplam varyansın $\% 74,998$ ini açıklamaktadır. Dolayısıyla bu sonuç, 14 değişkenle açıklanmak istenen finansal istikrarın üç bileşen altında toplandığını belirtmektedir. Bu sonuçlar ışığında üç temel bileşen birlikte, verideki toplam değişkenliğin \%74,998'ini açıkladığına göre finansal istikrar endeksinin oluşturulmasında üç temel bileşenin ağırlıklarının alınması yoluna gidilmiştir.

PCA yöntemiyle endeksin oluşturulmasında bir diğer aşama ise bileşenlerin yük matrisinin hesaplanmasıdır. Bileşen yük matrisi, hem değişkenlerin temel bileşenlerdeki ağırlıklarını hem de bu ağırlıkların yönünü tespit etmektedir. Temel bileşen yükü değerinin pozitif olması aynı yönde, negatif değerli olması zıt yönde ilişki olduğunu göstermektedir. Bu ilişki, temel bileşenlerin açıkladığı boyut ile değişkenler arasındaki istatistiksel bağıntı yapısı olarak tanımlanmaktadır (Yıkmaz, 2011: 111). 
Tablo 4'te gösterilen yük matrisi sonuçlarına bakıldığında, birinci temel bileşende 13 değişken yer alıp bunlardan 10 değişken finansal istikrar düzeyi ile aynı yönde, üç değişken ise zıt yönde ilişkilidir. İkinci temel bileşende, sermaye yeterlilik rasyosu en yüksek değeri almıştır ve bunun yanında dokuz değişken finansal istikrar ile aynı yönde üç değişken zıt yöndedir. Üçüncü temel bileşende ise en yüksek yük matrisi değerini cari denge/GSYIH ve genel bütçe dengesi/GSYiH değişkeni almıştır. Dolayısıyla yük matrisi tablosuna göre sermaye yeterlilik rasyosu değişkeni ikinci bileşenle, cari denge ve genel bütçe dengesi değişkenleri ise üçüncü bileşenle açıklandığı yorumu yapılabilir. Bundan sonraki aşamada üç bileşen birlikte ele alınarak finansal istikrar endeksi oluşturulacaktır.

Tablo 4. Temel Bileşen Analizi Yük Matrisleri

\begin{tabular}{|l|c|c|c|}
\hline \multirow{2}{*}{ m3 } & \multicolumn{3}{|c|}{ Bileşen } \\
\cline { 2 - 4 } tkh1 & 1 & 2 & 3 \\
kvdb/mbr & 0,977 & & \\
dibs & 0,975 & & \\
io & 0,833 & 0,194 & 0,15 \\
tbsgdp & 0,823 & 0,407 & 0,163 \\
tk/tm & 0,819 & 0,198 & $-0,11$ \\
btatk & 0,808 & 0,474 & $-0,114$ \\
syr & 0,69 & $-0,657$ & \\
lyo & 0,681 & 0,459 & \\
dth & & 0,81 & \\
ibfö/vg & $-0,644$ & 0,656 & \\
cd & 0,535 & $-0,639$ & $-0,107$ \\
gbd & $-0,351$ & 0,382 & 0,154 \\
& 0,347 & 0,168 & 0,777 \\
& $-0,282$ & $-0,235$ & 0,597 \\
\hline
\end{tabular}

Faktör yükleri hesaplandıktan sonra, her bir faktörleştirme yöntemi sonucunda elde edilen faktör stokları matrisi, faktörlerin varyans açıklama oranları dikkate alınarak ağılıklandııımıştır. Yani her bir faktör stokları matrisi varyans açıklama oranları ile çarpılıp toplanarak finansal istikrar endeksi oluşturulmuştur.

$$
\mathrm{GF}_{\mathrm{j}}=\sum_{i=n}^{k} \ddot{e} \mathrm{~F}_{\mathrm{ij}}
$$

$$
\begin{aligned}
& \mathrm{J}=1,2, \ldots, \mathrm{m} \\
& \ddot{e} \text { - varyans açıklama yüzdeleri }
\end{aligned}
$$

F-temel bileşen ağırlıkları olarak tanımlanan "Genel Faktör” skorları hesaplanmıştır (Özgür, 2003: 132).

Finansal istikrar endeksi oluşturulurken kullanılan finansal değişkenlerden toplam kredi hacmi, cari denge, genel bütçe dengesi ve toplam borç stoku verileri Gayri Safi Yurtiçi Hasılaya (GSYiH) oranlanmıştır. Veri seti aylık olduğundan dolayı GSYIH çeyreklik verileri alınarak Eviews 10' da Chow-Lin yöntemi ile aylık hale getirilmiştir.

\subsection{Veri Seti ve Yapısal Var Bulguları}

Çalışmada, 2011M1-2019M6 dönemleri arasında finansal istikrar değişkeni olarak oluşturulan finansal istikrar endeksi, 1 haftalık repo faiz oranı, nominal döviz kuru ve yurtiçi kredi hacmi değişkenleri kullanılmıştır. Mevsimsel etkileri barındırmasından dolayı yurtiçi kredi hacmi mevsimsellikten arındırılmış ve logaritması alınarak analize dahil edilmiştir (Tablo 5). Analizde kullanılan veriler; TCMB Elektronik Veri Dağıtım Sistemi (EVDS), Bankacılık Denetleme Düzenleme Kurumu (BDDK) ve Hazine ve Maliye Bakanlığı istatistikleri veri tabanlarından temin edilmiştir. 
Tablo 5. Değişkenlerin Tanımlanması

\begin{tabular}{|c|l|}
\hline rfo & 1 haftalık repo faiz oranı \\
$\mathbf{n d k}$ & Nominal döviz kuru \\
$\mathbf{y k h}$ & Yurtiçi kredi hacmi \\
pca & Finansal istikrar endeksi \\
\hline
\end{tabular}

Basit VAR modeli ilk olarak Sims (1980) tarafından ortaya atılmıştır. Sims'e göre VAR analizinde değişkenler arasındaki karşılıklı ilişkilerin belirlenmesi amaçlanmaktadır. VAR modeli, sistem içindeki her değişkenin kendi gecikmeli değeri ile modeldeki diğer değişkenlerin geçmiş değerleri arasındaki ilişkiyi gösteren dinamik bir sistemdir. Basit VAR modeli, bütün değişkenleri birlikte ele alır ve bunları bir sistem bütünlüğü içerisinde inceler. VAR modelinin diğer modellerden farkı ise içsel-dışsal değişken ayrımının söz konusu olmamasıdır. VAR modeli hata terimleri üzerine getirilen üçgensel kısıtlama sebebiyle iktisat teorisine uygun olmadığı yönünde ve modele dahil edilen değişkenlerin sıralamasının sonuçlar üzerinde etkilerinin olmaması yönünde eleştirilere maruz kalmıştır. Bundan dolayı Sims (1986), Bernanke (1986), Shapiro ve Watson (1988) tarafından "Yapısal VAR" modeli geliştirilerek basit VAR modelinin bu olumsuzlukları giderilmeye çalışılmıştır (Yalçın, 2018: 82). Yazarlar modelde yer alan dışsal şokların, doğrusal bileşimi olan sistemdeki hata terimlerinin ayırt edilmesi konusuna yoğunlaşmışlardır. Yapısal VAR modelinde, basit VAR modelinin tersine uygulanan kısıtlar iktisat teorisine dayandırılarak yapılmaktadır.

Genel olarak SVAR modeli aşağıdaki gibi tanımlanabilir:

$$
A y_{t}=A_{0}+A_{1} y_{t-1}+\cdots+A_{p} y_{t-p}+B \varepsilon_{t}
$$

Burada, $y_{t}(k \times 1)$ boyutlu durağan süreç olan içsel değişkenler vektörünü, $\mathrm{A}(k \times k)$ boyutlu katsayılar matrisi, B hata terimleri ile tahmin edilen katsayılar arasındaki ilişkiyi gösteren ve köşegen elemanları sıfırdan farklı olan bir matristir. Son olarak $\varepsilon_{t}$ de $(k \times 1)$ boyutlu, ak gürültü özelliğine sahip yapısal şoklar vektörüdür (Apaydın ve Şahin, 2017: 31). Yukarıda tanımlanan genel SVAR modelinde, değişkenler arasındaki eş-anlı etkileşimlerin varlı̆̆ı katsayılara ilişkin doğrudan tahmin sürecini imkansız kılmakta ve bu nedenle indirgenmiş biçimde tanımlanan denkleme intiyaç duyulmaktadır. (2) no'lu denkleminin indirgenmiş biçimi için denklemin her tarafı $A^{-1}$ ile çarpııırsa aşağıdaki sonuç elde edilmektedir:

$$
y_{t}=\Lambda_{0}+\Lambda_{1} y_{t-1}+\cdots+\Lambda_{P} y_{t-p}+\omega_{t}
$$

(3) no'lu denklemde; $\omega_{t}=A^{-1} B \varepsilon_{t}$ ifadesi, yapısal model ile indirgenmiş form modelinin hata terimleri arasındaki bileşik ilişkiyi göstermektedir. Bu bileşik ilişkinin ayrıştırılması işlemi etki-tepki analizi açısından önem taşımaktadır. Sistemde yer alan yapısal şokların ayrıştırılması için katsayı matrislerine $\left(m^{2}-m\right) / 2$ tane kısıt koymak gerekmektedir. Bu kısıtlarda değişkenlerin sıralanışı büyük önem taşımakta ve genel olarak kısa dönem kısıtları şeklinde adlandırılmaktadır. SVAR modelinde kısıtlar yapısal modelde belirtilen $A$ matrisine, $B$ matrisine ya da $A B$ eşanlı katsayı matrislerine konabilir. Sistemdeki ilk değişkenin en dışsal olması, diğer değişkenlerden gelen geçici şoklara tepki vermediği, son değişkenin en içsel olması ise, bu değişkenin hem kendi şoklarına hem de diğer değişkenlerden gelen şoklara tepki verdiği anlamına gelmektedir (Çiçek, 2005: 91). SVAR modelinde değişkenlerin sıralaması Granger nedensellik testi ile de belirlenebilmektedir. Ancak iktisadi teori bu sıralamayı belirlemede daha aktif rol üstlenmektedir. Dolayısıyla bu çalışmada değişkenlerin sıralaması teorik altyapıya göre belirlenmiştir. Çünkü Granger nedensellik testi, belirlenecek gecikme uzunluklarına duyarlı olduğundan yanıltıcı sonuçlar verebilmektedir (Lebe ve Bayat, 2011: 101).

Bu çalışmada kısa dönem kısıtlamalı SVAR modelinin tercih edilme nedeni büyük ölçüde gözlemlenebilen değişkenler arasındaki ilişkilerin ortaya konmasının amaçlanmış olmasıdır. Dolayısıyla çalışmada TCMB'nin uygulamış olduğu 1 haftalık repo faiz oranı aynı zamanda politika faiz oranı olarak ele 
alınmakta ve diğer değişkenlerden teorik beklentiler çerçevesinde etkilenmeyeceği öngörüldüğü için en dışsal değişken olarak düşünülmektedir.

Sermaye girişlerinin arttığı dönemlerde döviz kuru oynaklığının kontrol altına alınması ve kredi genişlemesinin yavaşlatılması finansal istikrarı sağlama açısından oldukça önemlidir. Sermaye hareketlerinde aşırı oynaklıklar döviz kurunda dalgalanmalara neden olmakta ve bu durum ülkede cari açık sorunu yaratmaktadır. Aynı zamanda TL'nin aşırı değerlenmesi de kredi arzını artıracağından bu durum ülke ekonomisinin kaynak dağılımı tahsisinin bozulmasına neden olacaktır. TCMB, uyguladığı faiz koridoru politikası çerçevesinde kısa vadeli sermaye akımlarını caydırmak amacıyla faiz koridorunu aşağı yönlü genişleterek söz konusu sermaye akımlarındaki dalgalanmalar sonucunda döviz kurunda oluşacak aşırı değerlenmeyi engelleyebilmektedir. Bunun sonucunda da kredi genişlemesi dolaylı olarak kontrol altına alınmaktadır. Tüm bu nedenlerden dolayı modelde ikinci değişken olarak nominal döviz kuru ve üçüncü değişken olarak da yurtiçi kredi hacmi yer almaktadır. Finansal istikrar endeksi ise diğer tüm değişkenlere bağımlı olarak tanımlandığından en içsel kabul edilmiştir ve modelde en sonda yer almaktadır.

Para politikası tepkisinin finansal istikrar üzerine etkisini Türkiye için 2011 sonrası dönem ele alınarak analiz etmek için değişkenler arasında eş anlı ve gecikmeli ilişkiyi dikkate alan yapısal VAR (SVAR) modeli matris formunda şu şekilde yazılabilir (Tetik ve Ceylan, 2015: 61):

$$
\left[\begin{array}{l}
r f o \\
n d k \\
y k h \\
p c a
\end{array}\right]=\left[\begin{array}{cccc}
a_{11} & 0 & 0 & 0 \\
a_{21} & a_{22} & 0 & 0 \\
a_{31} & a_{32} & a_{33} & 0 \\
a_{41} & a_{42} & a_{43} & a_{44}
\end{array}\right]\left[\begin{array}{l}
r f o_{t-i} \\
n d k_{t-i} \\
y k h_{t-i} \\
p c a_{t-i}
\end{array}\right]+\left[\begin{array}{l}
w_{1 t} \\
w_{2 t} \\
w_{3 t} \\
w_{4 t}
\end{array}\right]
$$

\section{Bulgular}

\section{1. Önsel Testler}

VAR modelinde önsel testler olarak değişkenlerin durağanlıkları test edilerek uygun gecikme uzunlukları ve otokorelasyon tahminleri elde edilecektir. Bu testler modelden anlamlı sonuçlar çıkarılması açısından önemlidir. Çalışmada elde edilen tüm tahminler JMulti paket programı ile yapılmıştır.

Zaman serisi analizlerinde, zaman serileri genellikle durağan değildir ve durağan olmayan zaman serileriyle çalışılması sahte regresyon sorunu ortaya çıkartabilir. Dolayısıyla öncelikle serilerin durağanlık testinin yapılması gerekmektedir.

VAR modelinin kurulabilmesi için değişkenlerin birim kök içermemesi gerekmektedir. Modeldeki değişkenlerin birim kök içermesi durumunda tahmin sonuçları anlamsız olacaktır. Literatürde serilerin durağanlıklarının araştırıması konusunda çoğunlukla Genişletilmiş Dickey Fuller (ADF) ve Phillips-Perron (PP) birim kök testleri kullanılmaktadır. Bu çalışmada da ADF ve PP birim kök testleri kullanılmıştır. (Tablo 6)

Tablo 6. Birim Kök Testleri

\begin{tabular}{|c|c|c|c|c|}
\hline \multirow{2}{*}{ Değişkenler } & \multicolumn{2}{|c|}{ ADF Testi } & \multicolumn{2}{|c|}{ PP Testi } \\
\hline & Düzey Hali & Birinci Farkı & Düzey Hali & Birinci Farkı \\
\hline rfo & $-1,311031(0,8796)$ & $-11,78390(0,000)^{*}$ & $-1,271656(0,8891)$ & $-11,69234(0,000)^{*}$ \\
\hline ndk & $-1,773504(0,7102)$ & $-8,775122(0,000)^{*}$ & $-1,528581(0,8133)$ & $-6,228075(0,000)^{*}$ \\
\hline ykh & $-1,047701(0,9318)$ & $-8,700301(0,000)^{*}$ & $-1,047701(0,9318)$ & $-8,655493(0,000)^{*}$ \\
\hline pca & $-0,294547(0,9898)$ & $-9,202119(0,000)^{*}$ & $-0,505611(0,9818)$ & $-9,196665(0,000)^{*}$ \\
\hline $\begin{array}{l}\text { Anlamlılık } \\
\text { Düzeyi }\end{array}$ & & Kritik & eğerler & \\
\hline $1 \%$ & $-4,051$ & $-4,052$ & $-4,051$ & $-4,052$ \\
\hline $5 \%$ & $-3,454$ & $-3,455$ & $-3,454$ & $-3,455$ \\
\hline $10 \%$ & $-3,153$ & $-3,153$ & $-3,153$ & $-3,153$ \\
\hline
\end{tabular}


Tablo 6'dan görüldüğü gibi ADF ve PP testi sonuçlarına göre sabit ve trendli modelde $\% 1, \% 5, \% 10$ anlamlılık düzeyinde tüm değişkenler düzeyde durağan değillerdir, yani birim kök vardır. Bu değişkenlerin birinci farkları alındığından durağan oldukları tespit edilmiştir. Dolayısıyla analize tüm değişkenlerin birinci farkları alınmış halleriyle devam edilmektedir.

VAR analizinde, modeldeki gecikme uzunluğu analiz sonuçlarını önemli ölçüde etkilemektedir. Gecikme uzunluğunun artması serbestlik derecesinin azalmasına neden olacaktır. Dolayısıyla optimal gecikme uzunluğu, serilerin birbirleri ile etkileşiminde bilgi kaybı yaşanmayacak kadar kısa, hata terimleri arasında otokorelasyona neden olmayacak kadar uzun olmalıdır. Literatürde uygun gecikme uzunluğunun tespiti konusunda yaygın olarak kullanılan testler, Akaike Bilgi Kriteri (AIC), Schwarz Bilgi Kriteri (SIC), Hannan-Quinn Bilgi Kriteri (HQ) ve Son Tahmin Hatası (FPE) testleridir. Bu bilgiler doğrultusunda optimal gecikme uzunluğuna ilişkin testlerin sonuçları tablo 7 'de verilmektedir.

Tablo 7. Uygun Gecikme Uzunluğu

\begin{tabular}{|l|c|}
\hline Test Türü & $\begin{array}{c}\text { Optimal Gecikme } \\
\text { Uzunluğu }\end{array}$ \\
\hline Akaike Bilgi Kriteri (AIC) & 3 \\
Son Tahmin Hatası (FPE) & 2 \\
Hannan-Quinn Bilgi Kriteri (HQ) & 2 \\
Schwarz Bilgi Kriteri (SIC) & 0 \\
\hline
\end{tabular}

Bu çalışmada optimal gecikme uzunluğu için Akaike Bilgi Kriterinin (AIC) daha doğru sonuçlar verdiği tespit edildiğinden optimal gecikme uzunluğu 3 olarak alınmıştır. Gecikme uzunluğunun 3 alınmasından sonra yapılan tahmin sonucunda modelde otokorelasyon ve heteroskedasticity sorunu olmadığı tespit edilmiştir.

Yapısal VAR tahminine geçmeden önce aynı derecede durağan olan değişkenler arasında eşbütünleşme ilişkisi olup olmadığı Johansen eşbütünleşme testi ile analiz edilmiştir. Yapılan test sonucunda değişkenler arasında eşbütünleşme ilişkisi olmadığı tespit edilmiştir. Dolayısıyla çalışmanın bu aşamasından sonra yapısal VAR tahminine geçilmiştir.

\subsection{Yapısal VAR (SVAR) Tahmini}

TCMB'nin 2010 yılından sonra uygulamaya başladığı geleneksel olmayan para politikaları uygulamalarının finansal istikrarı sağlamada hangi politika aracının etkili olduğunun araştırıldığı bu çalışmada, SVAR tahmininden önce değişkenler arasındaki nedensellik ilişkisi incelenmiştir (Tablo 8).

Tablo 8'de değişkenler arasındaki nedensellik ve eşanlılık ilişkisine bakıldığında, \%5 anlamlılık düzeyinde finansal istikrar endeksi dışındaki tüm değişkenler arasında nedensellik ilişkisinin yüksek olduğu yani finansal istikrar endeksinin (PCA) diğer değişkenlerin nedeni olmadığı tespit edilmektedir. Bu sonuç, yapısal VAR modelinde iktisat teorisine göre bu değişkenin son değişken olarak alınması ile uyumludur. Aynı zamanda yurt içi kredi hacmi (YKH) değişkeni dışındaki tüm değişkenler arasında da eşanlılık durumu olduğu tespit edilmiştir. Bu sonuç tahmin edilecek SVAR modeli için önemli bir başlangıçtır. Bu testler sonucunda SVAR modelini çalıştırmak mümkündür. SVAR modelinde etki-tepki analizine başlamadan önce her biri için ayrı ayrı tahmin yapılmış olup eşanlı katsayı tahmin sonuçları Tablo 9'da verilmiştir. 
Tablo 8. Granger Nedensellik ilişkisi Test Sonuçları

\begin{tabular}{|c|c|c|c|c|c|}
\hline \multicolumn{3}{|c|}{ Granger Nedensellik için Test-1 } & \multicolumn{3}{|c|}{ Eşanlılık Nedensellik için Test-1 } \\
\hline $\begin{array}{l}\mathrm{H}_{0}: \text { "RFO", "YKH,NDK,PCA" } \\
\text { ‘nın Granger nedeni değildir. } \\
H_{0}: \text { RED }\end{array}$ & $\begin{array}{l}\text { Test } \\
\text { statistic } \\
I=4,661\end{array}$ & $\begin{array}{l}\text { pval-F } \\
(\mathrm{I} ; 9,340) \\
=0,0001\end{array}$ & $\begin{array}{l}\mathrm{H}_{0}: \text { "RFO" ve "YKH,NDK,PCA" } \\
\text { arasında eşanlılık nedeni } \\
\text { yoktur. } \\
\mathbf{H}_{0}: \text { RED }\end{array}$ & $\begin{array}{l}\text { Test } \\
\text { statistic } \\
c=37,7936\end{array}$ & $\begin{array}{l}\text { pval- } \\
\text { Chi(c;3) } \\
=0,0000\end{array}$ \\
\hline \multicolumn{3}{|c|}{ Granger Nedensellik için Test-2 } & \multicolumn{3}{|c|}{ Eşanlılık Nedensellik için Test-2 } \\
\hline $\begin{array}{l}\mathrm{H}_{0}: \text { "NDK", "RFO,YKH,PCA" } \\
\text { 'nın Granger nedeni değildir. } \\
\mathrm{H}_{0}: \mathrm{RED}\end{array}$ & $\begin{array}{l}\text { Test } \\
\text { statistic } \\
I=2,4252\end{array}$ & $\begin{array}{l}\text { pval-F } \\
(1 ; 9,340) \\
=0,0111\end{array}$ & $\begin{array}{l}\mathrm{H}_{0} \text { : "NDK" ve "RFO,YKH,PCA" } \\
\text { arasında eşanlılık nedeni } \\
\text { yoktur. } \\
\mathrm{H}_{0} \text { :RED }\end{array}$ & $\begin{array}{l}\text { Test } \\
\text { statistic } \\
c=13,0113\end{array}$ & $\begin{array}{l}\text { pval- } \\
\text { Chi(c;3) } \\
=0,0046\end{array}$ \\
\hline \multicolumn{3}{|c|}{ Granger Nedensellik için Test-3 } & \multicolumn{3}{|c|}{ Eşanlılık Nedensellik için Test-3 } \\
\hline $\begin{array}{l}\mathrm{H}_{0}: \text { "YKH", "RFO,NDK,PCA" } \\
\text { 'nın Granger nedeni değildir. } \\
\mathrm{H}_{0}: \mathrm{RED}\end{array}$ & $\begin{array}{l}\text { Test } \\
\text { statistic } \\
I=2,9394\end{array}$ & $\begin{array}{l}\text { pval-F } \\
(1 ; 9,340) \\
=0,0023\end{array}$ & $\begin{array}{l}\mathrm{H}_{0} \text { : "YKH" ve "RFO,NDK,PCA" } \\
\text { arasında eşanlılık nedeni } \\
\text { yoktur. } \\
\mathrm{H}_{0} \text { :RED EDiLEMEZ }\end{array}$ & $\begin{array}{l}\text { Test } \\
\text { statistic } \\
c=3,2788\end{array}$ & $\begin{array}{l}\text { pval-Chi } \\
(\mathrm{c} ; 3) \\
=0,3506\end{array}$ \\
\hline \multicolumn{3}{|c|}{ Granger Nedensellik için Test-4 } & \multicolumn{3}{|c|}{ Eşanlılık Nedensellik için Test-4 } \\
\hline $\begin{array}{l}\mathrm{H}_{0}: \text { "PCA", "RFO,YKH,NDK" } \\
\text { 'nın Granger nedeni değildir. } \\
\mathrm{H}_{0}: \mathrm{RED}\end{array}$ & $\begin{array}{l}\text { Test } \\
\text { statistic } \\
I=1,6631\end{array}$ & $\begin{array}{l}\text { pval-F } \\
(1 ; 9,340) \\
=0,0966\end{array}$ & $\begin{array}{l}\mathrm{H}_{0}: \text { "PCA" ve "RFO,YKH,NDK" } \\
\text { arasında eşanlılık nedeni } \\
\text { yoktur. } \\
\mathrm{H}_{0} \text { :RED }\end{array}$ & $\begin{array}{l}\text { Test } \\
\text { statistic } \\
c=41,2140\end{array}$ & $\begin{array}{l}\text { pval-Chi } \\
(\mathrm{c} ; 3) \\
=0,0000\end{array}$ \\
\hline
\end{tabular}

Tablo 9. Eşanlı Katsayılar Tahmin Sonuçları

\begin{tabular}{|c|c|c|c|c|}
\hline Değişkenler & Rfo & Ykh & Ndk & Pca \\
\hline Rfo & $\begin{array}{l}a_{11} \\
\text { Tahmin: 0,7096 } \\
\text { Std.hata:0,0507 } \\
\text { t istatistiği:13,99 }\end{array}$ & 0,00 & 0,00 & 0,00 \\
\hline Ykh & $\begin{array}{l}a_{21} \\
\text { Tahmin: }-0,1207 \\
\text { Std.hata:0,0722 } \\
\text { t istatistiği:-1,67 }\end{array}$ & $\begin{array}{l}a_{22} \\
\text { Tahmin: } 33,3738 \\
\text { Std.hata:2,3838 } \\
\text { t istatistiği:13,99 }\end{array}$ & 0,00 & 0,00 \\
\hline Ndk & $\begin{array}{l}a_{31} \\
\text { Tahmin: 0,1934 } \\
\text { Std.hata:0,0740 } \\
\text { t istatistiği:2,61 }\end{array}$ & $\begin{array}{l}\text { a32 } \\
\text { Tahmin: }-29,7004 \\
\text { Std.hata:3,9832 } \\
\text { t istatistiği:7,45 }\end{array}$ & $\begin{array}{l}\text { a33 } \\
\text { Tahmin: } 92,2480 \\
\text { Std.hata: } 6,5891 \\
\text { t istatistiği: } 13,99\end{array}$ & 0,00 \\
\hline
\end{tabular}

Tabloya bakıldığında, ana köşegen katsayıları $\left(a_{i i}\right)$ bağımlı değişken katsayıları, diğer değişkenler ise $\left(a_{i j}\right)$ bağımsız değişken katsayılarıdır. Ana köşegen üzerindeki tüm katsayılar, SVAR modelindeki bağımlı değişkenlerin, kendi gecikmeleri ve diğer değişkenlerin gecikmeleri ile açıklanabildiğinden dolayı istatistiksel olarak anlamlıdır. Bağımlı değişken eşitliğin sol tarafına atılıp diğer değişkenler eşitliğin sağ tarafına atılarak yorumlanmaktadır. Dolayısıyla bağımlı değişkenlerin katsayıları işaret değiştirir.

pca $=\mathbf{0 , 2 9 7 0 r f o + 1 5 , 2 8 1 3 n d k - 8 , 9 9 0 0 y k h ~}$
$(0,0782)$
$(4,6431)$
$(9,3406)$

Tablo 9'da finansal istikrar endeksinin (PCA) sonuçlarına göre bir parametre hariç diğer parametreler istatistiki açıdan anlamlıdır ve modeldeki diğer değişkenleri de eşanlı olarak etkilemektedir. Genel olarak, SVAR modelinin eşanlı katsayılarının çoğu, değişkenler arasında gerçekleşen eşanlı etkileşimin teorik beklentileri ile uyumludur. 
Finansal istikrar göstergesi olarak kullanılan finansal istikrar endeksi (PCA), politika faizi olarak kullanılan 1 haftalık repo faiz oranı ve nominal döviz kuru değişkenlerinin gecikmeli değerlerinde meydana gelen değişmeler ile istatistiksel olarak anlamlı bir şekilde açıklanmaktadır. Ancak yurtiçi kredi hacmi değişkeninin finansal istikrar üzerinde istatistiksel olarak anlamlı bir katkısı bulunmamaktadır.

\subsection{Etki-Tepki Analizi}

SVAR modelinden elde edilen tahmin sonuçlarına yönelik yorumlamalar etki-tepki grafiklerine bakılarak yapılmaktadır. Etki-tepki analizi ile bir değişkende yaşanan bir standart hatalık şoka içsel değişkenlerin verdiği tepkiler grafiksel olarak gösterilmektedir. Tahmin edilen etki-tepki fonksiyonlarının dikey ekseninde, ilgili değişkene verilen şok karşısında diğer değişkenlerin tepkisinin yönü ile yüzde olarak büyüklüğü görülebilir. Yatay eksende ise, şokun verildikten sonraki 12 aylık süresi gösterilmektedir. Kesik çizgiler ise \%95 güven aralığını göstermekte ve sonuçların istatistiksel olarak anlamlılı̆ını tespit etmekte önemli yer tutmaktadır.

Şekil 1. Bir Standart Sapmalık Şokun Etki-Tepki Grafikleri
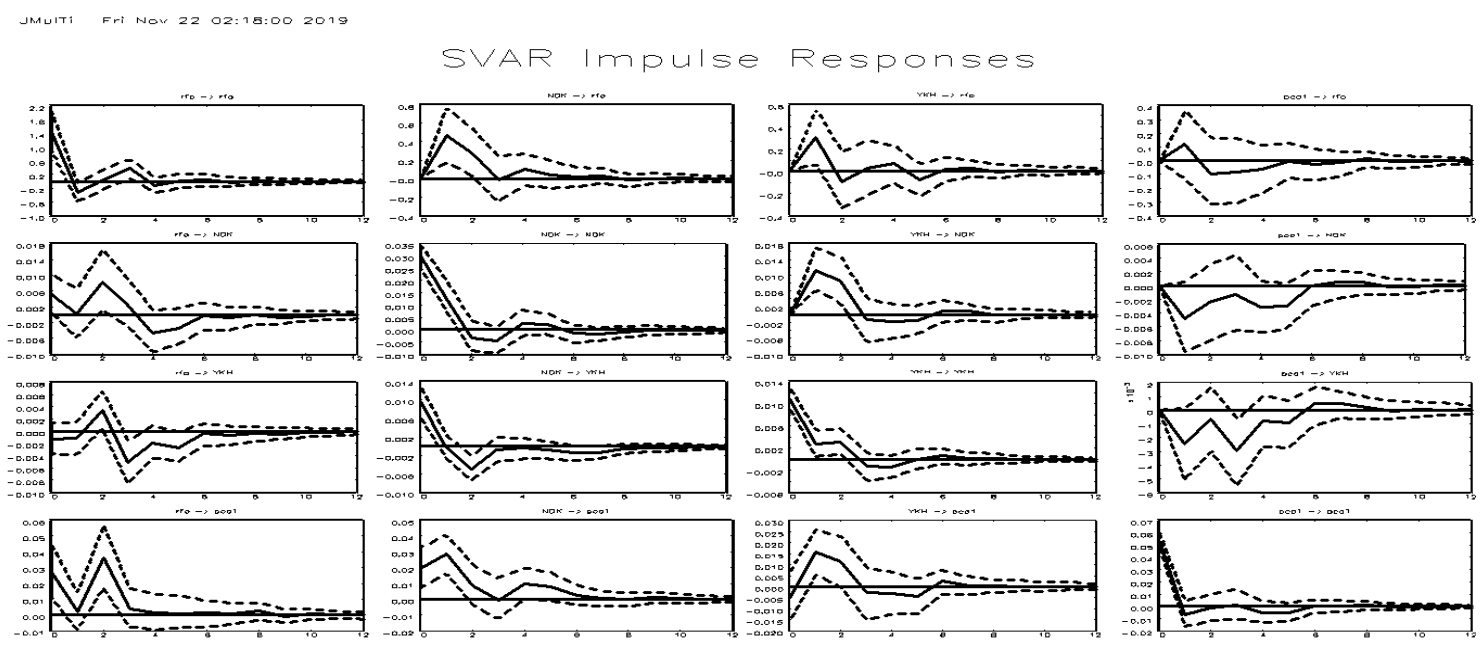

Şekil 1'deki düz çizgiler nokta etki-tepki tahminidir. Kesikli çizgiler ise bu tahminin \%95 Hall güven aralığında olduğunu göstermektedir.

Şekil 1'deki grafiklere bakıldı̆ıında bu çalışma için etki-tepki fonksiyonlarının dördüncü satırının yorumlanması önemlidir. Bu satır, bağımsız değişkenlerde meydana gelecek bir standart sapmalık şoka finansal istikrar endeksinin eşanlı ve gecikmeli tepkilerini göstermektedir. Politika faizi değişkenindeki bir standart sapmalık şoka finansal istikrar endeksi pozitif ve istatistiksel olarak anlamlı tepki vermektedir. Politika faiz oranı değişkeninde yaşanan bir şoka finansal istikrar endeksinin gecikmeli tepkileri 12 ay sonra ortadan kalkmaktadır. Bu durum TCMB'nin kriz dönemlerinde politika faiz oranını düşürerek bankaların fon maliyetlerinin azalmasını, dolayısıyla net faiz marjını ve bankaların karlılığını artırarak finansal istikrarı sağlama hedefiyle tutarlıdır.

İkinci olarak, nominal döviz kurunda meydana gelen şok karşısında finansal istikrar endeksi de pozitif yönlü ve anlamlı tepki vermektedir. Bu tepki istatistiksel olarak 3 aya kadar anlamlıdır. Bu sonuç, TCMB'nin finansal istikrarı sağlama amacıyla geleneksel olmayan para politikaları uygulamasında parasal aktarım mekanizması olarak döviz kuru kanalının daha etkin çalıştı̆̆ını göstermektedir. Buna ek olarak TCMB'nin haftalık repo ihalesi açmadığı günlerde istisnai gün uygulaması politikasıyla döviz kuru oynaklığının sınırlanması yoluyla finansal istikrarı sağlamaya çalıştığı yönündeki bulgularla da örtüşmektedir.

Son olarak yurt içi kredi hacmi değişkenindeki bir şoka karşılık finansal istikrar endeksinin verdiği tepkiye bakıldığında, bu tepkinin istatistiksel olarak anlamsız olduğu gözlenmektedir. Bu sonuç TCMB'nin finansal istikrarı sağlama yönündeki çalışmalarında parasal aktarım mekanizması olarak kredi kanalının etkin 
işlemediğini göstermektedir. Bu bulgu, literatürde Cambazoğlu ve Karaalp (2012) ve Akbaş vd. (2013)'nin yaptıkları çalışmalarda döviz kurunun daha etkin çalıştığı sonucu ile de örtüşmektedir. Aynı zamanda Örnek (2009) de yapmış olduğu çalışmada Türkiye için kredi kanalının etkin çalışmadığı sonucuna ulaşmıştır. Örnek (2009) bunun nedenini; Türkiye'de reel faiz oranlarının uzun yıllar çok yüksek seyretmesiyle birlikte bankaların sahip oldukları fonları devlet iç borçlanma senetlerine yönlendirdiğini, dolayısıyla bankaların finansal aracılık fonksiyonlarını gerçekleştiremediklerinden, reel sektör yatırımlarının finansmanı için banka dışı kaynaklara yönelmeleri olarak açıklamaktadır.

Tablo 10. Varyans Ayrıştırması

\begin{tabular}{|c|c|c|c|c|}
\hline \multicolumn{5}{|c|}{ PCA } \\
\hline Dönem & Repo Faizi & Nominal Döviz Kuru & Yurt içi kredi & Pca \\
\hline 1 & 0,18 & 0,10 & 0,01 & 0,71 \\
2 & 0,14 & 0,24 & 0,05 & 0,56 \\
3 & 0,31 & 0,19 & 0,06 & 0,44 \\
4 & 0,31 & 0,19 & 0,06 & 0,43 \\
5 & 0,30 & 0,20 & 0,06 & 0,43 \\
6 & 0,30 & 0,21 & 0,06 & 0,43 \\
7 & 0,30 & 0,21 & 0,06 & 0,43 \\
8 & 0,30 & 0,21 & 0,06 & 0,43 \\
9 & 0,30 & 0,21 & 0,06 & 0,43 \\
10 & 0,30 & 0,21 & 0,06 & 0,43 \\
11 & 0,30 & 0,21 & 0,06 & 0,43 \\
12 & 0,30 & 0,21 & 0,06 & 0,43 \\
\hline
\end{tabular}

Finansal istikrar endeksi değişkeninin (PCA), 1.dönem sonunda varyans değişimi \%71 oranında kendisinden kaynaklanırken, \%18'i faiz oranından, \%10'u kurdan \%1'i ise krediden kaynaklanmaktadır. 12 ay sonunda ise \%43'ü kendisi, \%30'u faiz oranı, \%21'i kur ve \%6'sı kredi tarafından açıklanmaktadır. 12 aylık dönem sonuna kadar finansal istikrar endeksindeki varyans değişimi üzerinde kendi etkisinin azaldığı, faiz oranı ve kur etkilerinin ise arttığı gözlenmektedir.

Varyans ayrıştırma tablosunda ortaya konan sonuçlar, SVAR tahminleri ve etki-tepki analizleri ile de tutarlıdır. Bu sonuç, TCMB tarafından uygulamaya konan faiz koridoru stratejisi ve istisnai gün uygulamalarının finansal istikrarın sağlanmasında etkili olduklarını göstermektedir. Faiz koridoru uygulamasının piyasa faizlerinin politika faizinden sapmasını önlemek için kullanıldığı ve bunun sonucunda da faiz kanalının işleyişini güçlendiren politika aracının faiz koridoru olduğu düşünülmektedir. Çalışmada çıkan sonuçlar literatürde Binici vd. (2016) çalışmasında, faiz koridoru uygulamasının Türkiye'de parasal aktarım mekanizması faiz kanalının işleyişini güçlendirdiği yönündeki bulgularıyla örtüşmektedir. Aynı şekilde finansal istikrar endeksinin varyans değişimi üzerinde döviz kuru etkisinin artması da Merkez Bankası'nın finansal istikrarı sağlamak amacıyla uyguladığı istisnai gün uygulamasının etkili olduğu sonucuna ulaşılmaktadır. Bu sonuç, Merkez Bankası'nın istisnai gün uygulamasıyla döviz kuru oynaklığını sınırlayarak TL'nin değer kazanmasını amaçlaması finansal istikrarı sağlama amacıyla örtüşmektedir. Dolayısıyla TCMB, finansal istikrarı sağlayabilmek için etkin olarak faiz koridoru stratejisini ve istisnai gün politikalarını sürdürmelidir.

\section{Sonuç}

$\mathrm{Bu}$ çalışmanın temel amacı, TCMB tarafından uygulanan geleneksel olmayan para politikası araçlarından faiz koridoru, istisnai gün ve kredi genişlemesinin, temel bileşenler analizi yolu ile oluşturulan finansal istikrar üzerindeki etkilerini SVAR yöntemi ile incelemektir. 2008 küresel finansal krizinin finansal piyasalarda neden olduğu dalgalanmaların reel sektör üzerinde yarattığı olumsuz etkiler, birçok ülkede finansal istikrarın önemini bir kez daha ortaya koymuştur.

Çalışmadan elde edilen bulgulara bakıldığında TCMB'nin 2010 yılından sonra finansal istikrarı sağlama yönündeki adımlarının politika faizi ve istisnai gün uygulaması yoluyla olduğu gözlenmektedir. Çalışmada 1 
haftalık repo faiz oranı değişkeninde meydana gelen bir şok karşısında finansal istikrar endeksini pozitif ve anlamlı yönde etkilemesi, TCMB'nin kriz dönemlerinde politika faiz oranını düşürerek finansal istikrarı sağlamayı hedeflemesiyle örtüşmektedir. Nominal döviz kurunda meydana gelen bir şok karşısında finansal istikrar endeksinin pozitif ve anlamlı olduğu gözlenmektedir. Bu durum TCMB'nin para politikası araçlarından "istisnai gün uygulaması" politikası ile tutarlıdır. Yurtiçi kredi hacmi değişkenine verilen bir şok ise finansal istikrar endeksini pozitif yönde etkilemektedir, ancak bu istatistiksel olarak anlamlı değildir. Dolayısıyla bu durum, TCMB'nin finansal istikrarı sağlama yönündeki uygulamalarında politika faizi ve istisnai gün uygulamasını daha etkin kullandığı şeklinde yorumlanabilir. Aynı zamanda parasal aktarım mekanizması olarak finansal istikrarın sağlanmasında hem faiz kanalının hem de döviz kuru kanalının etkin olduğu, kredi kanalının ise etkin olmadığı sonucuna ulaşılmıştır. Bu sonuçlara bakıldığında TCMB'nin 2010 yılından sonra uygulamaya başladığı geleneksel olmayan para politikaları ile finansal istikrarı sağlama amacına ulaşmaya çalıştığı söylenebilmektedir.

Çalışmadan elde edilen bulgular, kısmen literatürde var olan çalışmalar ile benzer sonuçlar verse de buradaki asıl önemli katkının finansal istikrar endeksinin teorik altyapıdan gelen birçok makroekonomik değişkeni içerecek şekilde, temel bileşenler analizi yolu ile hesaplanmış olması ve geleneksel olmayan para politikası araçlarının etkinliğini ortaya koymasıdır.

\section{Beyan ve Açıklamalar (Declarations and Disclosures)}

Yazarların Etik Sorumlulukları (Ethical Responsibilities of Authors): Bu çalışmanın yazarları, araştırma ve yayın etiği ilkelerine uyduklarını kabul etmektedirler.

Çıkar Çatışması (Conflicts of Interest): Yazarlar tarafından herhangi bir çıkar çatışması beyan edilmemiştir.

Finansal Destek (Funding): Yazarlar, çalışmanın hazırlanması ve/veya yayınlanması sürecinde herhangi bir finansal destek almamışlardır.

Yazar Katkı Oranı (Author Contributions): Yazarlar, çalışmaya olan katkılarını şu şekilde beyan etmişlerdir: Kavramlaştırma ve çalışma dizaynı, R. Ceylan; verilerin toplanması, Ş. Felek; verilerin analizi ve sonuçların yorumlanması, Ş. Felek ve R. Ceylan; çalışmanın ilk/taslak halinin yazııması, Ş. Felek; çalışmanın gözden geçirilmesi ve düzenlenmesi/düzeltilmesi, R. Ceylan. Çalışmanın ilk ve son hali tüm yazarlar tarafından okunmuş ve onaylanmış olup, yazarlar çalışmalarıyla ilgili sorumluluğu kabul etmektedirler.

intihal Denetimi (Plagiarism Checking): Bu çalışma, intihal tarama programı kullanılarak intihal taramasından geçirilmiştir.

\section{Kaynaklar}

Akbaş, Y., Zeren, F., \& Özekicioğlu, H. (2013). Türkiye'de parasal aktarım mekanizması: Yapısal VAR analizi. Cumhuriyet Üniversitesi iktisadi ve Idari Bilimler Dergisi, 14(2), 187-198.

Akçelik, Y., Basçı, E., Ermişoğlu, E., \& Oduncu, A. (2013). The Turkish approach to capital flow volatility. Türkiye Cumhuriyet Merkez Bankası, Working Paper: 13/06.

Aktaş, C. (2011). Finansal istikrar analizi bağlamında Türkiye İçin finansal istikrar endeksi önerisi. Ankara Üniversitesi Sosyal Bilimler Enstitüsü, Doktora Tezi, Ankara.

Angelopoulou, E., Balfoussia, H., \& Gibson, H. D. (2014). Building a financial conditions index for the Euro area and selected Euro area countries: What does it tell us about the crisis? Economic Modelling, 38, 392-403.

Apaydın, Ş., \& Şahin. H. (2017). Türkiye'de kısa vadeli sermaye akımlarının iktisadi dalgalanmalar üzerindeki etkileri: Bir uzun dönem kısıtlı SVAR modeli. Politik Ekonomik Kuram, 1, 22-72.

Arıkan, C., Görgün, S., \& Yalçın, Y. (2018). Parasal aktarım sürecinde faiz koridorunun yeri. Maliye Dergisi, 174, 1-25.

Bagliano, F. C., \& Favero, C. A. (1998). Measuring monetary policy with VAR models: An Evaluation. European Economic Review, 42, 1069-1112.

Belke, M., \& Kaya, H. (2017), Türkiye'de para politikalarının kredi kanalı aktarımı: Var yaklaşımı. Finans Ekonomi ve Sosyal Araştırmalar Dergisi, 2(3), 185-208. 
Bernanke, B. S. (1986). Alternative explanations of money-income correlation. Carnegie-Rochester Conference Series on Public Policy, 25, 49-100.

Bernanke, B. S., \& Blinder, A. S. (1992). The federal funds rate and the channels of monetary transmission. The American Economic Review, 82(4), 901-921.

Bernanke, B., Reinhart, V., \& Sack, B. (2004). Monetary policy alternatives at the zero bound: An empirical assessment. Federal Reserve Board Finance and Economics Discussion Paper 2004-48.

Binici, M., Kara, H., \& Özlü, P., (2016). Faiz koridor ve banka faizleri: Parasal aktarım mekanizmasına dair bazı bulgular. TCMB Çalışma Tebliği, No:16/8, Ankara.

Borio, C., \& Drehmann, M. (2009). Assessing the risk of banking crises - revisited. BIS Quarterly Review, March, 29-46.

Borio, C., \& Disyatat, P. (2009). Unconventional monetary policies: An appraisal. BIS Working Papers, No:292.

Cambazoğlu, B., \& Karaalp, H. S. (2012). Parasal aktarım mekanizması döviz kuru kanalı: Türkiye örneği. Yönetim ve Ekonomi Dergisi, 19(2), 53-66.

Cengiz, V. (2009). Parasal aktarım mekanizması işleyişi ve ampirik bulgular. Erciyes Üniversitesi iktisadi ve Idari Bilimler Fakültesi Dergisi, (33), 225-247.

Cotarelli, C., \& Courelis, A., (1994). Financial structure, bank lending rates, and the transmission mechanism of monetary policy. IMF Working Paper 94/39.

Cuaresma, J. C., \& Gnan, E. (2008). Four monetary policy strategies in comparison: How to deal with financial instability? Monetary Policy \& The Economy Q3/08.

Çevik, F. (2016). Sermaye akımı oynaklığı ve kredi büyümesinde yeni para politikasının önemi. Elektronik Sosyal Bilimler Dergisi, 15(57), 710-718.

Çiçek, M. (2005). Türkiye'de parasal aktarım mekanizması: Var (vektör otoregresyon) yaklaşımıyla bir analiz. iktisat, işletme ve Finans, 20(233), 82-105.

Dell' Ariccia, G., Igan, D., Laeven, L., \& Tong, H. (2015). Policies for macrofinancial stability: How to deal with credit booms? In Economic Policy 62nd Panel Meeting Hosted luxembourg (pp. 16-17).

Dunteman, G. H. (1989). Principal components analysis, quantitative applications in the social sciences. USA: Sage Publications.

Eroğlu, N., \& Kara, F. (2017). Türkiye'de makro ihtiyati para politikası araçlarının makroekonomik değişkenlere etkisinin var analizi ile incelenmesi. İstanbul iktisat Dergisi, 67(2), 59-88.

Farmer, R. E. (2012). Qualitative easing: How it works and why it matters. National Bureau of Economic Research, Working Paper 18421.

Fendoğlu, M. C. (2015). Finansal istikrar açısından makro ihtiyati araçların etkisi: Türkiye ve seçilmiş ülkeler için sistem GMM yaklaşımı. Gazi Üniversitesi Sosyal Bilimler Enstitüsü, Yayınlanmış Yüksek Lisans Tezi, Ankara.

Glocker, C., \& Towbin, P. (2012). Reserve requirements for price and financial stability: When are they effective? International Journal of Central Banking, 8(1), 65-114.

Goodhart, C., \& Hofmann, B. (2001). Asset prices, financial conditions, and the transmission of monetary policy. In Conference on Asset Prices, Exchange Rates, and Monetary Policy. Stanford University (2-3).

Kara, H., Özlü, P., \& Ünalmış, D. (2015). Türkiye için finansal koşullar endeksi. Central Bank Review, 15(3), 41-73.

$\mathrm{Kıl}$ I, E. N. (2019). New trends in central banking in Turkey: A study on the reserve option mechanism and the asymmetric interest rate. The Journal of Accounting and Finance, Özel Sayı, 185-200.

Lebe, F., \& Bayat, T. (2011). Taylor kuralı: Türkiye için bir vektör otoregresif model analizi. Ege Akademik Bakış, 11/Özel Sayı, 95-112.

Lim, C., Columba, F., Costa, A., Kongsamut, P., Otani, A., Saiyid, M., Wezel, T., \& Wu, X. (2011). Macroprudential policy: What instruments and how to use them? IMF Working Paper No. 11/238.

Mishkin, F. (1995). Symposium on the monetary transmission mechanism. Journal of Economics Perspective, 9(3), 3-10.

OECD, (2005). Handbook on constructing composite indicators: methodology and user guide. OECD Statistic Working Papers, OECD Publishing.

Oktar, S., \& Dalyancı, L. (2011). Türkiye ekonomisinde para politikasının cari işlemler dengesi üzerindeki etkisinin ekonometrik analizi. Marmara Üniversitesi i.i.B.F. Dergisi, 30(1), 1-22.

Osorio, M. C., Unsal, D. F., \& Pongsaparn, M. R. (2011). A quantitative assessment of financial conditions in Asia. International Monetary Fund, No:11-70. 
Örnek, i. (2009). Türkiye'de parasal aktarım mekanizması kanallarının işleyişi. Maliye Dergisi, (156), 104-125.

Özgür, E. (2003). Çok değişkenli istatistiksel analiz yöntemleri ve bir uygulama. Gazi Üniversitesi Sosyal Bilimler Enstitüsü, Yayınlanmamış Doktora Tezi, Ankara.

Papademos, L. (2006). Price stability, financial stability and efficiency and monetary policy. Vice President of The ECB at The Third Conference of The Monetary Stability Foundation on "Challenges to The Financial System - Ageing and Low Growth", Frankfurt.

Sanar, F. (2014), Finansal istikrar kavramı ve Türkiye için finansal istikrar endeksi önerisi. Gazi Üniversitesi Sosyal Bilimler Enstitüsü, Yüksek Lisans Tezi, Ankara.

Shapiro, M., \& Watson, M. (1988). Sources of business cycle fluctuations. In S. Fisher (ed.). NBER Macroeconomic Annual, 3, 111-156.

Sims, C. A. (1986). Are forecasting models usable for policy analysis? Federal Reserve Bank of Minneapolis Quarterly Review, 10(1), 2-16.

Sinclair, P. J. N. (2000). Central banks and financial stability. Bank of England Quarterly Bulletin, 40, 377-391.

Snowdon, B., \& Vane, H. (2005). Modern makroekonomi temelleri, gelişimi ve bugünü (Çeviren: B. Kablamacı). Ankara: Efil Yayınevi.

Tetik, M., \& Ceylan, R. (2015). Faiz koridoru stratejisinin hisse senedi fiyatları ve döviz kuru üzerine etkisinin incelenmesi. Business and Economics Research Journal, 6(4), 55-69.

Tiryaki, G. (2012). Finansal istikrar ve bankacılık düzenlemeleri (1990-2010 Türkiye tecrübesi ışığında). İstanbul: Türkiye Bankalar Birliği (TBB), Yayın No:289.

Tovar, C. E., Garcia-escribano, M., \& Martin, M. V. (2012). Credit growth and the effectiveness of reserve requirements and other macroprudential instruments in latin america. IMF Working Paper.

Tunalı, H., \& Yalçınkaya, Y. (2016). Geleneksel olmayan para politikası uygulamasında enflasyon ile döviz kuru arasındaki nedensellik ilişkisinin analizi. iktisat Fakültesi Mecmuası, 66(2), 61-111.

TCMB, (2012). 2013 yılı para ve kur politikası. Ankara.

Vural, U. (2013). Geleneksel olmayan para politikalarının yükselişi. Uzmanlık Yeterlilik Tezi, Türkiye Cumhuriyet Merkez Bankası İletişim ve Dış İlişkiler Genel Müdürlüğü, Ankara.

Yalçın, E. (2018). Küresel kriz sonrası Türkiye'de parasal aktarım mekanizmasının etkinliği. Pamukkale Üniversitesi Sosyal Bilimler Enstitüsü, Yayımlanmamış Yüksek Lisans Tezi, Denizli.

Yıkmaz, R. F. (2011). Sürdürülebilir kalkınmanın ölçülmesi ve Türkiye için yöntem geliştirilmesi. Uzmanlık Tezi, DPT Sosyal Sektörler ve Koordinasyonlar Genel Müdürlüğü, Yayın No:2820, Ankara. 
This Page Intentionally Left Blank 